\title{
CERVICAL SPONDYLOTIC MYELOPATHY: IS A COMBINED APPROACH NECESSARY?
}

\author{
MIELOPATIA CERVICAL ESPONDILÓTICA: A ABORDAGEM COMBINADA É NECESSÁRIA? \\ MIELOPATÍA CERVICAL ESPONDILÓTICA: ¿EL ABORDAJE COMBINADO ES NECESARIO?
}

\author{
Kelsen de Oliveira Teixeira ${ }^{1}$, luis Enrioue Moncada Moreno², Thiago Dantas Matos ${ }^{1}$, Rodrigo Barra Calado Fleury ${ }^{1}$, Herton Rodrigo Tavares Costa ${ }^{2}$, \\ Helton luiz Aparecido Defino²
}

1. Universidade de São Paulo, Faculdade de Medicina de Ribeirão Preto, Postgraduate Program in Applied Locomotor Apparatus Sciences, Department of Biomechanics, Medicine and Rehabilitation of the Locomotor Apparatus, Ribeirão Preto, SP, Brazil.

2. Universidade de São Paulo, Faculdade de Medicina de Ribeirão Preto, Department of Biomechanics, Medicine and Rehabilitation of the Locomotor Apparatus, Ribeirão Preto, SP, Brazil.

\begin{abstract}
Objective: Cervical spondylotic myelopathy (CSM) is the main cause of spinal dysfunction in adults. The type of surgical approach to treatment is not well defined in the literature. The objective is to report the results obtained through isolated posterior decompression in patients with a previous indication of the combined approach for the treatment of cervical spondylotic myelopathy. Methods: This is a therapeutic study with level of evidence II, according to the Oxford classification table. Ten patients who underwent isolated posterior approach surgery for the treatment of cervical spondylotic myelopathy were evaluated through imaging and questionnaires (visual analog scale, mJOA-Br scale - Brazilian Portuguese version of the Modified Japanese Orthopedic Association Scale, and Neck Disability Index (NDI)), comparing pre- and postoperative results. Results: Late evaluation of the 10 patients was performed in the period ranging from 24 to 36 months (mean of 30.3 months \pm 7.25 ) following surgery. The comparison of the clinical and radiological parameters in all patients showed a statistical difference in relation to the preoperative scales applied and to the degree of cervical lordosis ( $p<0.05)$, evidencing improvement after decompression and posterior fixation of the cervical spine. Conclusions: The isolated posterior approach (decompression, fixation and arthrodesis) allowed the clinical and radiological improvement of patients with cervical spondylotic myelopathy and who had an indication of the complementary anterior approach. Level of evidence II; Retrospective study.
\end{abstract}

Keywords: Spinal Osteophytosis; Spinal Cord Diseases; Cervical Vertebrae.

\section{RESUMO}

Objetivo: A mielopatia cervical espondilótica (MCE) é a principal causa de disfunção medular nos adultos. O tipo de abordagem cirúrgica para o tratamento não é bem definido na literatura. O objetivo é relatar os resultados obtidos por meio da descompressão posterior isolada nos pacientes com indicação prévia da abordagem combinada para o tratamento da mielopatia cervical espondilótica. Métodos: Trata-se de um estudo terapêutico com nível de evidência II, conforme a tabela de classificação Oxford. Dez pacientes submetidos apenas à abordagem cirúrgica posterior para tratamento de mielopatia cervical espondilótica foram avaliados por meio de exames de imagem e de questionários (escala visual analógica, escala mJOA-Br - Versão em Português da Escala Modificada da Sociedade Japonesa de Ortopedia e escala de incapacidade cenvical - Neck Disability Index - NDI), comparando os resultados pré e pós-operatórios. Resultados: A avaliação tardia dos 10 pacientes foi realizada no período que variou de 24 a 36 meses (média de 30,3 meses \pm 7,25) de pós-operatório. A comparação dos parâmetros clínicos e radiológicos em todos os pacientes mostrou diferença estatística com relação ao pré-operatório para as escalas aplicadas e para o grau de lordose cenvical $(p<0,05)$, evidenciando a melhora depois da descompressão e da fixação posterior da coluna cervical. Conclusões: A abordagem posterior isolada (descompressão, fixação e artrodese) permitiu a melhora clínica e radiológica de pacientes com mielopatia cervical espondilótica e que tinham indicação da abordagem anterior complementar. Nível de evidência II; Estudo retrospectivo.

Descritores: Osteofitose Vertebral; Doenças da Medula Espinhal; Vértebras Cervicais.

\section{RESUMEN}

Objetivo: La mielopatía cervical espondilótica (MCE) es la principal causa de disfunción medular en los adultos. El tipo de abordaje quirúrgico para el tratamiento no está bien definido en la literatura. El objetivo es relatar los resultados obtenidos por medio de la descompresión posterior aislada en los pacientes con indicación previa del abordaje combinado para el tratamiento de la mielopatía cervical espondilótica. Métodos: Se trata de un estudio terapéutico con nivel de evidencia II, conforme a la tabla de clasificación Oxford. Diez pacientes sometidos únicamente al abordaje quirúrgico posterior para el tratamiento de la mielopatía cervical espondilótica fueron evaluados mediante exámenes de imagen y cuestionarios (escala analógica visual, escala mJOA-Br - versión en portugués de la escala modificada de la Sociedad Japonesa de Ortopedia y escala de incapacidad cervical - Neck Disability Index - NDI), comparando los resultados pre y postoperatorios. Resultados: La evaluación tardía de los 10 pacientes fue realizada en el período que varió de 24 a 36 meses (promedio de 30,3 meses \pm 7,25) de postoperatorio. La comparación de los parámetros clínicos y radiológicos en todos los pacientes mostró diferencia estadística con

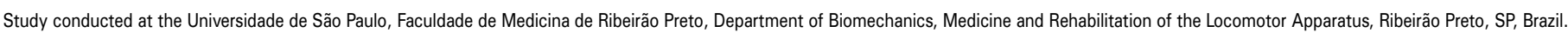
Correspondence: Kelsen de Oliveira Teixeira. Rua Prudente de Morais 888, Ed. latajái, ap. 93, Centro, Ribeirão Preto, SP, Brasil. 14015-100. kelsenteixeira@gmail.com 
relación al preoperatorio para las escalas aplicadas y para el grado de lordosis cervical $(p<0,05)$, evidenciando la mejora después de la descompresión y de la fijación posterior de la columna cervical. Conclusiones: El abordaje posterior aislado (descompresión, fijación y artrodesis) permitió la mejora clínica y radiológica de pacientes con mielopatía cervical espondilótica y que tenían indicación del abordaje anterior complementario. Nivel de evidencia II; Estudio retrospectivo.

Descriptores: Osteofitosis espinal; Enfermedades de la Médula Espinal; Vértebras Cervicales.

\section{INTRODUCTION}

Cervical spondylotic myelopathy (CSM) is the most serious consequence of degenerative cervical spine disease and is the main cause of spinal cord dysfunction in adults. ${ }^{1}$ The constellation of degenerative changes in the cervical spine, characterized by degeneration of the intervertebral discs and facet joints, alterations in sagittal alignment, ossification of the posterior longitudinal ligament (OPLL) and hypertrophy of the yellow ligament lead to a reduction in the diameter of the vertebral canal and compression of the spinal cord..$^{2-3}$ Spinal cord compression can be uni- or multisegmental and, together with the sagittal alignment of the cervical spine, guide the therapeutic decision. ${ }^{4}$

In general, the anterior approach to the cervical spine is indicated in uni- or bisegmental compression and the posterior approach is used in patients with compression in three or more vertebral segments. The parameters for the indication of a combined (anterior and posterior) approach are not well-defined in the relevant literature and it has been indicated in patients with multilevel disease who present anterior and posterior compression evidenced by radiographic examinations and by static or dynamic magnetic resonance. ${ }^{5}$ The presence of cervical kyphosis is also considered an indication for the combined approach to cervical lordosis reconstruction. ${ }^{6}$

We observed empirically that the clinical conditions of the group of patients with degenerative cervical spine myelopathy who were indicated for a combined approach (decompression and fixation) according to the criteria mentioned, improved significantly after decompression and posterior fixation. In these patients, the improvement in their clinical conditions after a posterior approach contraindicated the need to perform the additional anterior decompression surgery, even in patients with loss of cervical lordosis.

Clinical improvement after the posterior approach in patients with cervical myelopathy and indication for the combined approach motivated the evaluation and reporting of the results in this group of patients. The objective of the study was to report the results obtained by means of isolated posterior compression in patients with a previous indication of the combined approach to treat cervical spondylotic myelopathy and who improved significantly following posterior decompression.

\section{METHODS}

In the period from February 2014 to December 2017, 10 patients were identified with cervical spondylotic myelopathy involving at least three levels of the cervical spine, who had been indicated for the combined surgical approach, whose surgical treatment was limited to the posterior approach, due to improvement in clinical conditions following the surgical procedure (laminectomy and fixation), and who did not require complementary treatment by means of the anterior approach. The study was approved by the Institutional Review Board of the Hospital das Clínicas of the Faculdade de Medicina de Ribeirão Preto (opinion number 3.252.518) and all patients signed the informed consent form to participate in the study.

The demographic patient data are shown in Table 2. Eight patients were male $(80 \%)$ and two were female $(20 \%)$ ranging in age from 50 to 83 years $(64.5$ years $\pm 9,1)$. Three levels of the cervical spine were affected in eight patients and four levels were affected in two patients. All patients had signs of degeneration and anterior and posterior compression of the cervical spinal cord, as evidenced by complementary imaging examinations. Patients submitted to cervical surgery for spinal cord disease secondary to tumors, infections, or trauma were excluded from the study, as were those submitted to revision surgery. Posterior decompression surgery associated with fixation and arthrodesis was performed in all the patients. Fixation was performed by means of vertebral fixation using lateral mass screws or pedicle screws. The pedicle screws were used in the caudal cervical vertebrae (C6 and/or C7) in seven patients (70\%). Extension of the vertebral canal decompression was performed from C3 to C6.

The patients were evaluated using preoperative and late postoperative clinical and radiographic parameters. The clinical parameters used were the visual analog scale for cervical and upper limb pain, the mJOA-Br scale (Brazilian Portuguese version of the Modified Japanese Orthopedic Association scale) ${ }^{7}$, (Table 1) and the cervical disability scale (Neck Disability Index-NDI). ${ }^{8}$ The radiographical assessment was conducted using AP and lateral radiographs of the cervical spine and the parameters analyzed were the cervical lordosis measurement (Cobb angle between C2 and C7),

Table 1. Brazilian Portuguese Version of the Modified Japanese Orthopedic Association Scale.

\begin{tabular}{|c|c|}
\hline \multicolumn{2}{|r|}{ Brazilian Portuguese Version of the Modified Japanese Orthopedic Association Scale } \\
\hline \multirow{6}{*}{$\begin{array}{l}\text { I - Motor dysfunction scores of the } \\
\text { upper extremities }\end{array}$} & 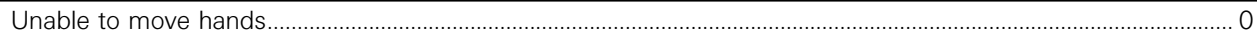 \\
\hline & Unable to eat $w / a$ spoon, but able to move hands \\
\hline & Unable to button shirt, but able to eat w/a spoon \\
\hline & Able to button shirt w/great difficulty ........................... \\
\hline & Able to button shirt $\mathrm{w} / \mathrm{mild}$ difficulty........................... \\
\hline & 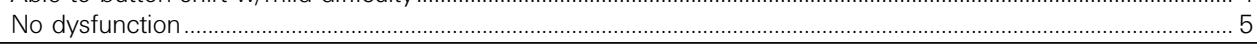 \\
\hline \multirow{8}{*}{$\begin{array}{l}\text { II - Motor dysfunction score of the } \\
\text { lower extremities }\end{array}$} & 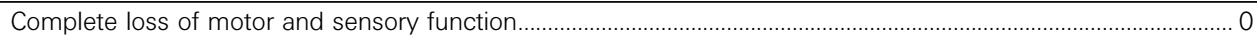 \\
\hline & Sensory preservation w/o ability to move legs............. \\
\hline & 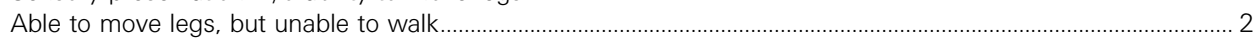 \\
\hline & Able to walk on flat floor w/walking aid (cane or crutch). \\
\hline & Able to go up and/or down the stairs w/handrail \\
\hline & Moderate-to-severe lack of stability, but able to walk up and/or down stairs w/o handrail ................................ 5 \\
\hline & Mild lack of stability, but walks w/alternating steps w/o help \\
\hline & No dysfunction \\
\hline \multirow{4}{*}{$\begin{array}{l}\text { III - Sensory dysfunction score of } \\
\text { upper extremities }\end{array}$} & Complete loss of hand sensation \\
\hline & 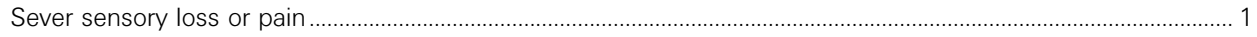 \\
\hline & 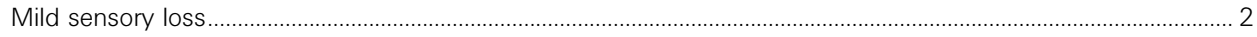 \\
\hline & 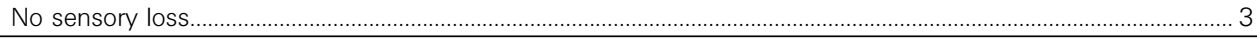 \\
\hline \multirow{4}{*}{ IV - Sphincter dysfunction score } & 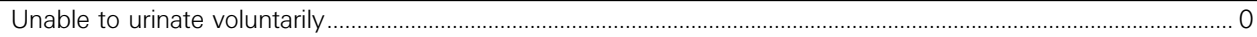 \\
\hline & 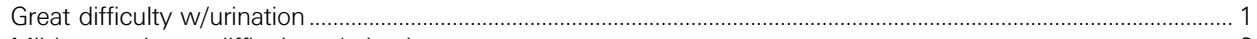 \\
\hline & 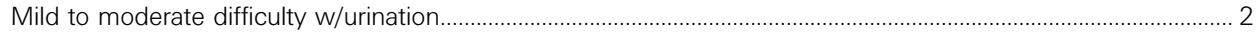 \\
\hline & Normal urination \\
\hline
\end{tabular}


Table 2. Demographic data and absolute scores of the clinical evaluation scales and cervical lordosis.

\begin{tabular}{|c|c|c|c|c|c|c|c|c|c|c|c|c|c|}
\hline \multicolumn{14}{|c|}{ Pacientes com Mielopatia Cervical Espondilótica Submetidos a Abordagem Cirúrgica Via Posterior. } \\
\hline \multirow[b]{2}{*}{ Patient } & \multirow[b]{2}{*}{ Age } & \multirow[b]{2}{*}{ Sex } & \multirow[b]{2}{*}{ Levels } & \multicolumn{2}{|c|}{ Cervical Lordosis } & \multicolumn{2}{|c|}{ mJOA-Br } & \multicolumn{2}{|c|}{ NDI } & \multicolumn{2}{|c|}{ Cervical VAS } & \multicolumn{2}{|c|}{ Upper Limb VAS } \\
\hline & & & & Pre-op & Post-op & Pre-op & Post-op & Pre-op & Post-op & Pre-op & Post-op & Pre-op & Post-op \\
\hline 1 & 65 & M & 3 & $20^{\circ}$ & $41^{\circ}$ & 11 & 17 & $6(12 \%)$ & 0 & 10 & 1 & 10 & 0 \\
\hline 2 & 69 & M & 4 & $0^{\circ}$ & $3^{\circ}$ & 13 & 15 & $20(40 \%)$ & $3(6 \%)$ & 7 & 0 & 0 & 0 \\
\hline 3 & 83 & M & 3 & $2.8^{\circ}$ & $3.8^{\circ}$ & 11 & 16 & $32(71.1 \%)$ & $14(31.1 \%)$ & 10 & 4 & 0 & 0 \\
\hline 4 & 51 & $\mathrm{~F}$ & 3 & $8.5^{\circ}$ & 10.5 & 12 & 19 & 33 (66\%) & $11(22 \%)$ & 10 & 3 & 10 & 4 \\
\hline 5 & 64 & M & 3 & $20.8^{\circ}$ & $22.8^{\circ}$ & 4 & 13 & $33(73.3 \%)$ & $8(17.7 \%)$ & 0 & 0 & 10 & 1 \\
\hline 6 & 68 & M & 3 & $2.2^{\circ}$ & $11.9^{\circ}$ & 12 & 13 & $18(36 \%)$ & $17(34 \%)$ & 7 & 7 & 7 & 7 \\
\hline 7 & 64 & $\mathrm{~F}$ & 3 & $28^{\circ}$ & $30^{\circ}$ & 6 & 11 & $29(64.4 \%)$ & $14(31.1 \%)$ & 6 & 2 & 8 & 2 \\
\hline 8 & 69 & M & 3 & $25.6^{\circ}$ & $26^{\circ}$ & 12 & 16 & 32 (71.1\%) & $2(4.4 \%)$ & 8 & 1 & 9 & 2 \\
\hline 9 & 62 & M & 3 & $21^{\circ}$ & $27.6^{\circ}$ & 18 & 18 & $20(44.4 \%)$ & $13(28.8 \%)$ & 7 & 5 & 0 & 0 \\
\hline 10 & 50 & M & 4 & ${ }^{*}-3.4^{\circ}$ & $0.1^{\circ}$ & 8 & 17 & 22 (44\%) & $5(10 \%)$ & 9 & 3 & 10 & 4 \\
\hline
\end{tabular}

the consolidation of the arthrodesis and changes in the implants used (breakage or loosening). Descriptive statistical analysis of the parameters was conducted, and non-parametric statistical methods were used to compare the pre- and postoperative conditions of the patients using the Wilcoxon test. The level of significance applied was $0.05(p<0.05)$.

\section{RESULTS}

The 10 patients evaluated in this study showed significant improvements in preoperative clinical symptoms after decompression and posterior cervical fixation. The complementary anterior approach was not performed due to improvement of the clinical conditions of the patients. Long-term evaluation of the patients was conducted in the timeframe ranging from 24 to 36 months (mean of 30.3 months \pm 7.25 ) following surgery. The evaluation of pre- and postoperative clinical and radiographic parameters revealed statistical differences in all parameters assessed, (Table 3) with significant improvement in the postoperative scores, indicating that the isolated posterior approach was sufficient to achieve improvement.

The comparison of the clinical parameters (modified Japanese Orthopedic Association (mJOA-Br) scale, the Neck Disability Index (NDI) and the visual analog scale (VAS)) and the pre-operative and follow-up radiological parameters showed statistical difference, (Table 3 and Figure 1) demonstrating patient improvement after decompression and posterior fixation of the cervical spine.

When comparative analysis was performed between the preand postoperative periods for the different clinical evaluation scales (NDI, mJOA-Br, cervical VAS and upper limb VAS), there were statistical differences between the absolute measurement values. (Figures 2 and 3)

The preoperative cervical lordosis values were greater than 20 degrees in only five patients and one of the patients had cervical segment kyphosis. In the postoperative period a statistically significant increase in lordosis from the preoperative values was observed. However, cervical lordosis values less than 20 degrees were also

Table 3. Statistical significance of the comparison between clinical and radiographic parameters in the preoperative and late follow-up periods.

\begin{tabular}{c|c}
\hline Methods/Statistics & p-value \\
\hline Cervical Lordosis & 0.005793 \\
\hline mJOA-Br & 0.00903 \\
\hline NDI & 0.005889 \\
\hline Cervical VAS & 0.01368 \\
\hline Upper Limb VAS & 0.03401 \\
\hline
\end{tabular}

mJOA-BR: Modified Japanese Orthopedic Association Scale. NDI: Neck Disability Index. VAS: Visual Analog Scale. observed in five patients. (Table 2) Despite the low cervical lordosis angle values of these patients, significant improvement in the clinical parameters was observed in the assessment. In the radiographical evaluation, no complications related to loosening, implant breakage or lack of consolidation of the arthrodesis were observed.

In all the patients, when the postoperative conditions were evaluated in relation to the preoperative conditions, quantitative improvement was observed in all the evaluation tools administered: the modified Japanese Orthopedic Association scale (mJOA-Br), the Neck Disability Index (NDI) and the visual analog scale (VAS). Preoperative (cervical spine radiographs and magnetic resonance) and postoperative (cervical spine radiographs) imaging examinations are presented in Figures 4 and 5.

\section{DISCUSSION}

In this retrospective study of a series of patients, we observed that decompression and posterior fixation of the cervical spine resulted in significant clinical and radiological improvement in those patients and that the isolated posterior approach was sufficient to achieve good outcomes and avoid anterior approach intervention.

The treatment of cervical spondylotic myelopathy (CSM) is still a controversial topic, mainly in terms of the most indicated surgical approach as it relates to the number of segments affected by the disease and the degree of involvement of the different cervical structures. ${ }^{9}$ In this context, given the possibility of a less invasive, single access surgery and, consequently, less surgical morbidity, treating patients with three or more levels affected by CSM via isolated posterior approach with decompression and arthrodesis can be effective in terms of clinical improvement, even in the presence of significant loss of cervical lordosis and incomplete postoperative restoration of sagittal balance. A significant gain in cervical lordosis can be achieved through posterior approach alone, as evidenced by the statistical results of this study. Although sagittal alignment and cervical spinal cord dysfunction are not well documented in the literature, ${ }^{10}$ the presence of kyphotic deformity of the cervical spine can increase the overload on the anterior cervical elements and accelerate the degeneration process in adjacent structures and, consequently, cervical myelopathy. ${ }^{11}$ In this regard, some studies, such as that of Kimura et al., report poor postoperative results in patients with kyphotic deformity of the cervical segment submitted to decompression via standalone posterior laminoplasty. ${ }^{12}$

Although the importance of sagittal alignment with maintenance of the physiological cervical spine lordosis is well-established ${ }^{13,14}$ and despite the related limitations of this study, such as a small sample of operated patients and the fact that, with the exception of cervical lordosis, the parameters were not measured for objective 


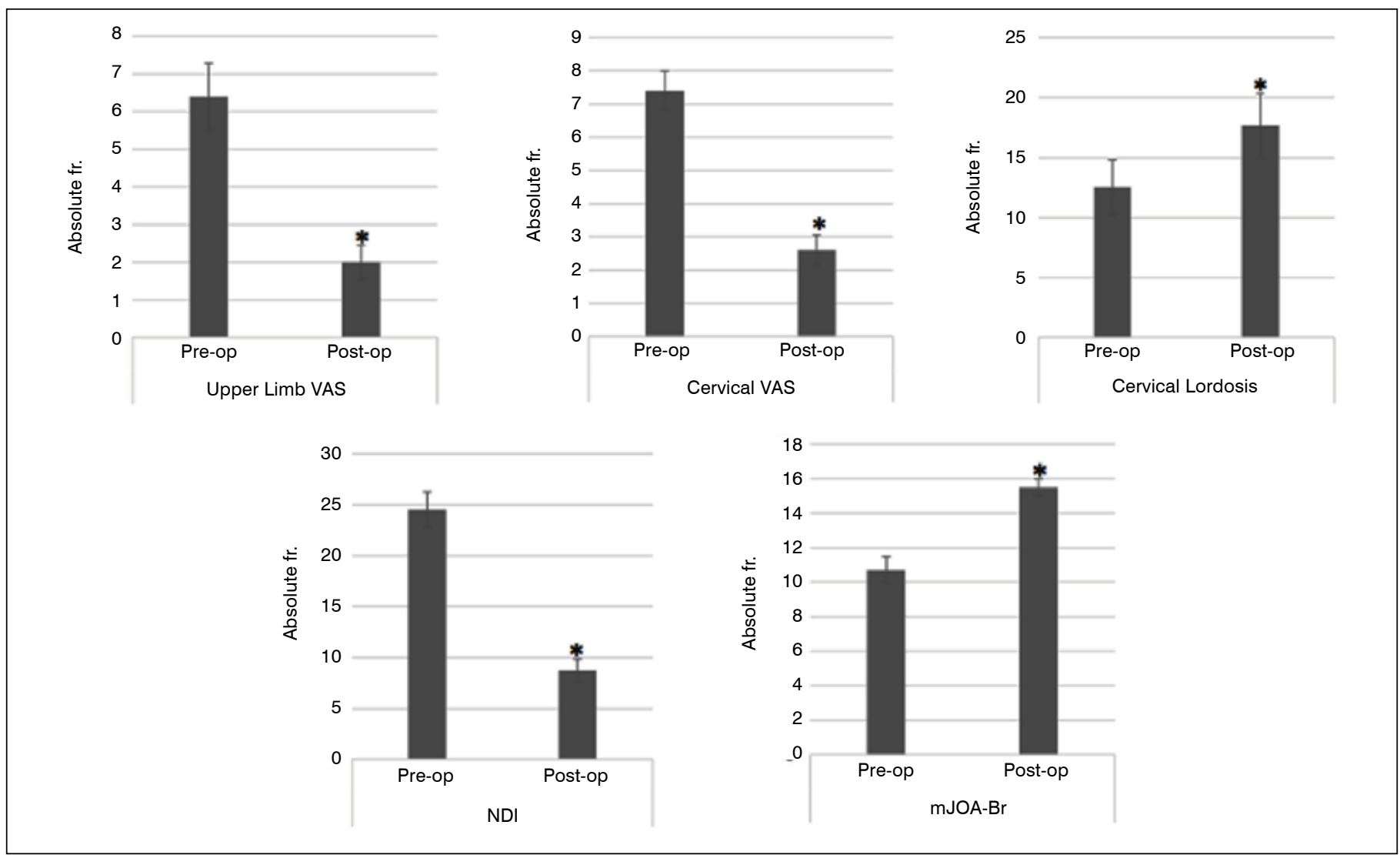

Figure 1. This figure shows the bar graphs as absolute values in the pre- and postoperative periods for each clinical evaluation scale: visual analog scale for cervical pain (cervical VAS), visual anallog scale for upper limb pain (upper limb VAS), Neck Disability Index (NDI) and the Brazilian Portuguese version of the Modified Japanese Orthopedic Association scale (mJOA-Br). The last graph shows the absolute pre- and postoperative.

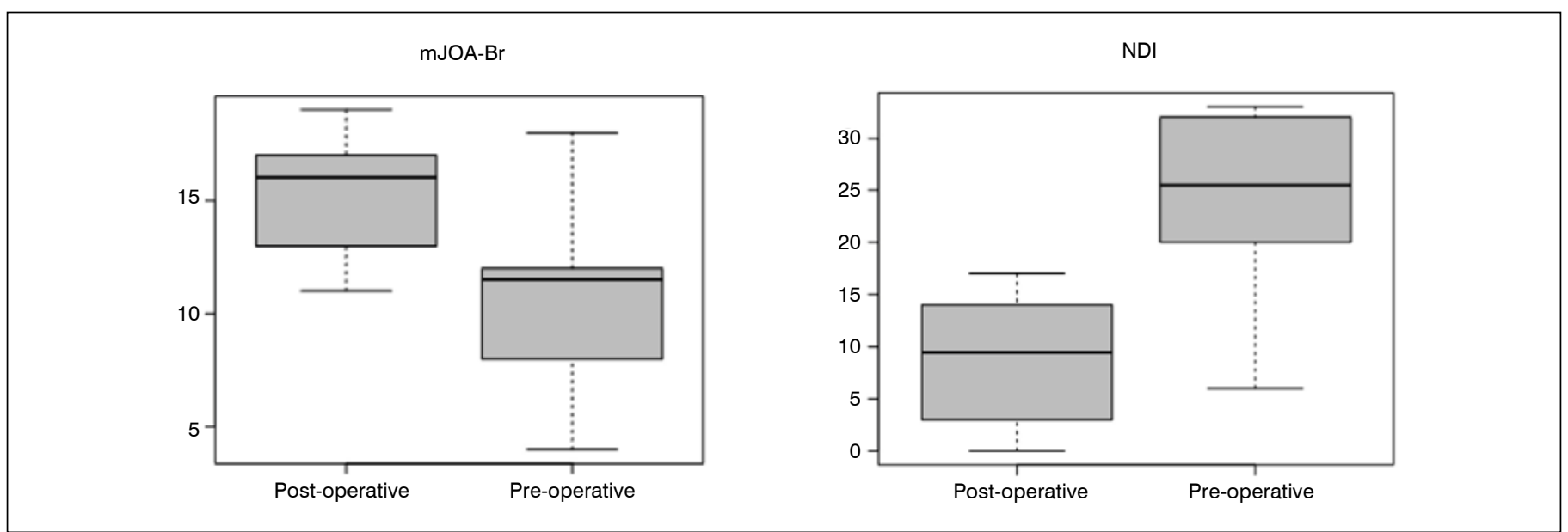

Figure 2. Comparative analysis of the patients submitted to surgery for treatment of cervical spondylotic myelopathy. NDI and mJOA-Br data were used. The Wilcoxon test was used for this analysis with a significance of 0.05. * $p$-value 0.05.

evaluation of pre- and postoperative sagittal balance, we observed that even the patients with cervical lordosis loss (five patients) and without correction of sagittal alignment following a posterior surgical approach (Figure 4) had improved symptoms, with a significant reduction in pain, as measured by the visual analog scale (VAS), compared to the preoperative period, even though axial pain is a potential issue, especially in patients submitted to the posterior approach alone. ${ }^{15}$ This suggests, in concordance with several works published in the literature, that, in patients with CSM, adequate decompression of neural elements is more important to the clinical outcome than restoration of regional cervical alignment ${ }^{16}$ even though recent studies have demonstrated that patients with more severe cervical kyphosis prior to surgery have less significant postoperative improvement of myelopathy symptoms regardless of the type of surgical approach. ${ }^{17}$

There are also prospective multicenter studies in the literature that report similar postoperative results for CSM patients submitted to circumferential approach (anterior and posterior access) cervical surgery, as compared to patients who underwent only posterior approach with decompression and fixations, when the cervical lordosis parameters and the Nurick scores were evaluated. 4,16

In addition to the number of cervical segments affected by spondylotic myelopathy, the degree of degeneration of the different anterior and posterior anatomical cervical structures, impairment of sagittal balance as already discussed, and factors inherent to 
Cervical VAS

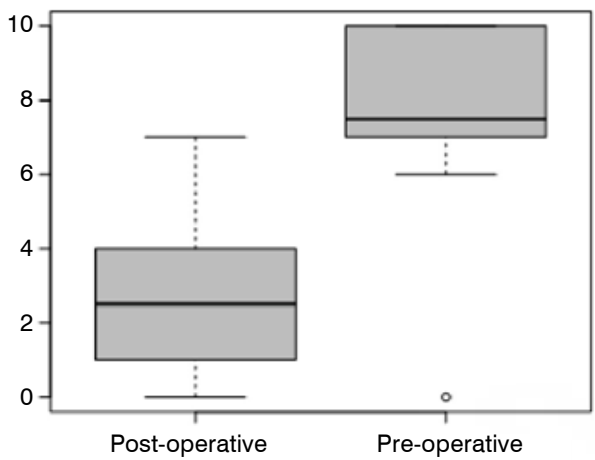

Upper Limb VAS

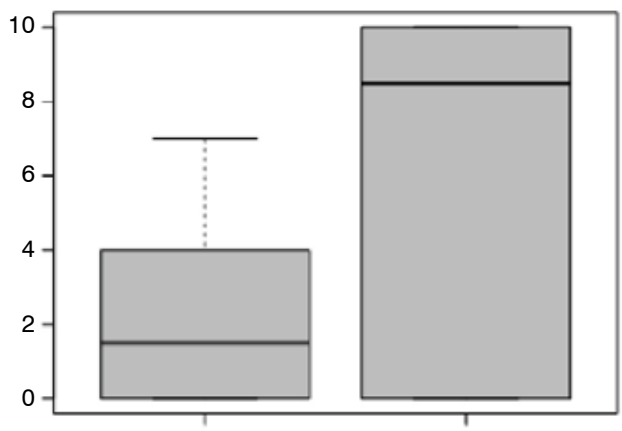

Post-operative

Pre-operative

Figure 3. Comparative analysis of the patients submitted to surgery for the treatment of cervical spondylotic myelopathy. The quantitative results from the visual analog scale (VAS) for cervical pain and pain radiating to the upper limbs were used for the analysis, with a significance level of 0.05 . ${ }^{*} p$-value $p<0.05$.
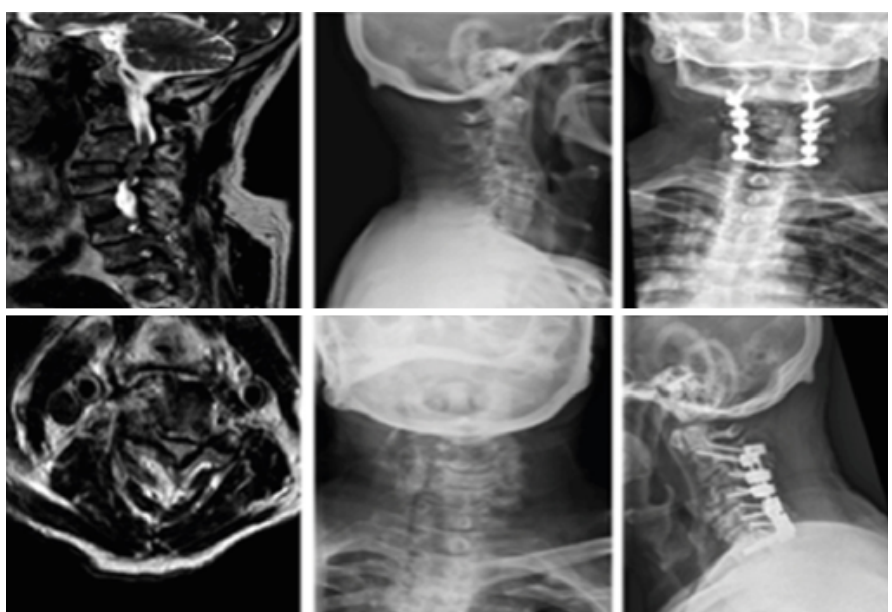

Figure 4. Sagittal and axial magnetic resonance cuts with signs of severe myelopathy and kyphosis of the cervical segment. Postoperative radiographs with posterior approach decompression and instrumentation from C2 to C7. Pedicle screws were used in C7 and lateral mass screws in the other levels.

the surgeon, such as preference for a particular surgical technique influence notably the choice of treatment with a wide variation in the choice of the type of surgical approach (anterior, posterior or combined). ${ }^{18}$ In general, comparative studies that evaluate the results of patients operated on by anterior approach with those of patients submitted to posterior approach, especially laminoplasty, concluded that the clinical outcomes in CSM patients are similar. ${ }^{15,19}$ However, complications are more frequent in patients operated on via the anterior surgical approach. ${ }^{20,21}$

Also, as regards complications in CSM patients with clinical conditions and radiological changes that require a combined surgical approach, isolated posterior access would be advantageous because of the lower incidence of complications, the improvement achieved, and the reduced surgical trauma to the patient caused by this type of surgery, as evidenced by this study. As for the postoperative assessment, studies report a high incidence of complications in patients with more than three affected levels who undergo anterior access surgery, especially those related to the graft and instrumentation or to the surgical approach itself, such as dysphagia and dysphonia. ${ }^{22-25}$ Moreover, some studies in the literature suggest that, in patients with anterior compression at various levels associated with a narrow canal, isolated anterior surgery may increase the risk of spinal cord injury in the stenotic canals by compression of the dura mater and of the spinal cord itself against the posterior bone structures and the posterior longitudinal ligament. In the presence
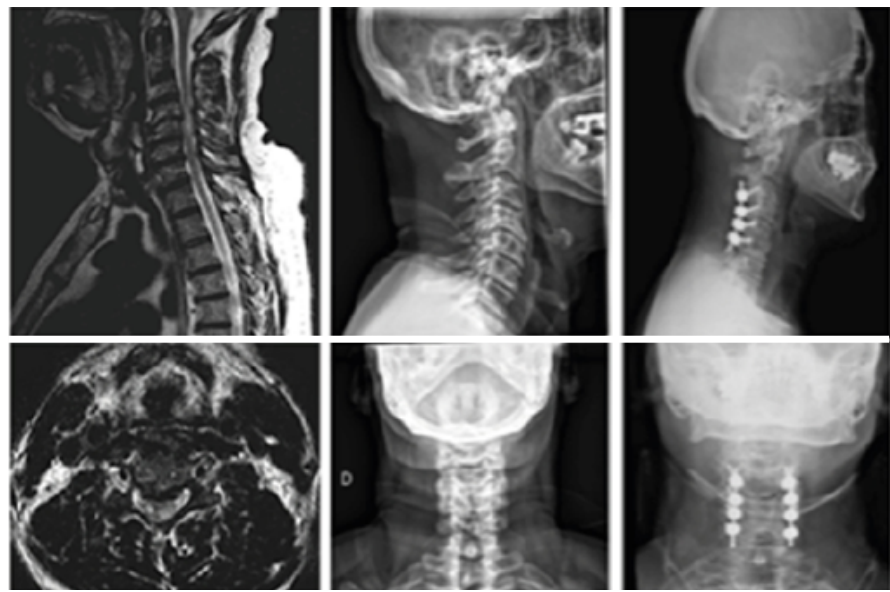

Figure 5. Sagittal and axial magnetic resonance cuts with multisegmental cervical stenosis and involvement of the anterior and posterior structures. Preoperative AP and lateral radiographs with loss of cervical lordosis. Postoperative radiographs after decompression and C3-C6 instrumentation.

of central stenosis, development of adjacent level compression after an anterior approach can also compromise the spinal cord. ${ }^{26}$

Considering the clinical and radiological results of the CSM patients in this study who underwent isolated posterior surgery without requiring complementary anterior approach surgery, the idea that posterior approach spinal canal decompression followed by instrumentation for arthrodesis is sufficient for the adequate treatment of patients with this condition is feasible, even in the presence of the degenerative involvement of the anterior and posterior elements of the cervical spine and loss of lordosis of this segment, implying an even lower postoperative complication rate and possibly an earlier clinical recovery due to reduced surgical aggression as compared to the combined access surgical approach.

\section{CONCLUSION}

The isolated posterior approach (decompression, fixation and arthrodesis) allowed clinical and radiological improvement in patients with cervical spondylotic myelopathy and who presented an indication of the complementary anterior approach. Significant improvement in the clinical and radiological parameters (cervical lordosis and cervical sagittal balance) was observed following the isolated posterior approach.

All authors declare no potential conflict of interest related to this article. 
CONTRIBUTION OF THE AUTHORS: Each author made significant individual contributions to this manuscript. KOT: preparation of the project, data collections, writing and revision. LEMM: data collection and writing. TDM: preparation of the project and writing. RBCF: data collection. HRTC: data collection. HLAD: preparation of the project, project coordination, writing and review.

\section{REFERENCES}

1. Fehlings MG, Tetreault LA, Riew KD, Middleton JW, Wang JC. A Clinical Practice Guideline for the Management of Degenerative Cervical Myelopathy: Introduction, Rationale, and Scope. Global Spine J. 2017;7(3 Suppl):21S-7S. doi: $10.1177 / 2192568217703088$.

2. Klineberg E. Cervical spondylotic myelopathy: a review of the evidence. Orthop Clin North Am. 2010;41(2):193-202. doi: 10.1016/j.ocl.2009.12.010

3. Liu T, Xu W, Cheng T, Yang HL. Anterior versus posterior surgery for multilevel cervical myelopathy, which one is better? A systematic review. Eur Spine J. 2011;20(2):224-35. doi: 10.1007/s00586-010-1486-7.

4. Fehlings MG, Barry S, Kopjar B, Yoon ST, Arnold P, Massicotte EM, et al. Anterior versus posterior surgical approaches to treat cervical spondylotic myelopathy: outcomes of the prospective multicenter AOSpine North America CSM study in 264 patients. Spine (Phila Pa 1976). 2013:38(26):2247-52. doi: 10.1097/BRS.0000000000000047.

5. Konya D, Ozgen S, Gercek A, Pamir MN. Outcomes for combined anterior and posterior surgical approaches for patients with multisegmental cervical spondylotic myelopathy. J Clin Neurosci. 2009;16(3):404-9. doi.org/10.1016/i.jocn.2008.07.070.

6. Mummaneni PV, Haid RW, Rodts GE. Combined ventral and dorsal surgery for myelopathy and myeloradiculopathy. Neurosurgery. 2007;60(1 Supp1 1):S82-9. doi: 10.1227/01. NEU.0000215355.64127.76.

7. Augusto MT, Diniz JM, Dantas FLR, Oliveira MF, Rotta JM, Botelho RV. Development of the Portuguese Version of the Modified Japanese Orthopaedic Association Score: Cross-Cultural Adaptation, Reliability, Validity, and Responsiveness. World Neurosurg. 2018;116:e1092-e7. doi: 10.1016/j.wneu.2018.05.173.

8. Vernon H, Mior S. The Neck Disability Index: a study of reliability and validity. J Manipulative Physiol Ther. 1991;14(7):409-15.

9. Bapat MR, Chaudhary K, Sharma A, Laheri V. Surgical approach to cervical spondylotic myelopathy on the basis of radiological patterns of compression: prospective analysis of 129 cases. Eur Spine J. 2008;17(12):1651-63. doi: 10.1007/s00586-008-0792-9.

10. Ferch RD, Shad A, Cadoux-Hudson TA, Teddy PJ. Anterior correction of cervical kyphotic deformity: effects on myelopathy, neck pain, and sagittal alignment. J Neurosurg. 2004;100(1 Suppl Spine):13-9. doi: 10.3171/spi.2004.100.1.0013.

11. Hilibrand AS, Yoo JU, Carlson GD, Bohlman HH. The success of anterior cervical arthrodesis adjacent to a previous fusion. Spine (Phila Pa 1976). 1997;22(14):1574-9. doi: 10.1097/00007632-199707150-00009.

12. Kimura I, Shingu H, Nasu Y. Long-term follow-up of cervical spondylotic myelopathy treated by canal-expansive laminoplasty. J Bone Joint Surg Br. 1995;77(6):956-61.

13. Chavanne A, Pettigrew DB, Holtz JR, Dollin N, Kuntz C. Spinal cord intramedullary pressure in cervical kyphotic deformity: a cadaveric study. Spine (Phila Pa 1976). 2011;36(20):161926. doi: 10.1097/BRS.0b013e3181fc17b0.

14. Ruangchainikom M, Daubs MD, Suzuki A, Hayashi T, Weintraub G, Lee CJ, et al. Effect of cervical kyphotic deformity type on the motion characteristics and dynamic spi- nal cord compression. Spine (Phila Pa 1976). 2014;39(12):932-8. doi: 10.1097/ BRS.0000000000000330.

15. Sakaura H, Hosono N, Mukai Y, Ishii T, Iwasaki M, Yoshikawa H. Long-term outcome of laminoplasty for cervical myelopathy due to disc herniation: a comparative study of laminoplasty and anterior spinal fusion. Spine (Phila Pa 1976). 2005;30(7):756-9. doi: 10.1097/01. brs.0000157415.79713.7e.

16. Patel S, Glivar P, Asgarzadie F, Cheng DJW, Danisa O. The relationship between cervical lordosis and Nurick scores in patients undergoing circumferential vs. posterior alone cervical decompression, instrumentation and fusion for treatment of cervical spondylotic myelopathy. J Clin Neurosci. 2017;45:232-5. doi: 10.1016/j. jocn.2017.07.009.

17. Shamji MF, Mohanty C, Massicotte EM, Fehlings MG. The Association of Cervical Spine Alignment with Neurologic Recovery in a Prospective Cohort of Patients with Surgical Myelopathy: Analysis of a Series of 124 Cases. World Neurosurg. 2016;86:112-9. doi: 10.1016/j.wneu.2015.09.044.

18. Irwin ZN, Hilibrand A, Gustavel M, McLain R, Shaffer W, Myers M, et al. Variation in surgical decision making for degenerative spinal disorders. Part II: cervical spine. Spine (Phila Pa 1976). 2005;30(19):2214-9. doi: 10.1097/01.brs.0000181056.76595.f7.

19. Hillard VH, Apfelbaum RI. Surgical management of cervical myelopathy: indications and techniques for multilevel cervical discectomy. Spine J. 2006;6(6 Suppl):242S-51S. doi: 10.1016/j.spinee.2006.05.005.

20. Wada E, Suzuki S, Kanazawa A, Matsuoka T, Miyamoto S, Yonenobu K. Subtotal corpectomy versus laminoplasty for multilevel cervical spondylotic myelopathy: a long-term followup study over 10 years. Spine (Phila Pa 1976). 2001;26(13):1443-7; discussion 8. doi: 10.1097/00007632-200107010-00011.

21. Yonenobu K. Hosono N, Iwasaki M. Asano M. Ono K. Laminoplasty versus subtotal corpectomy. A comparative study of results in multisegmental cervical spondylotic myelopathy. Spine (Phila Pa 1976). 1992;17(11):1281-4.

22. Hilibrand AS, Fye MA, Emery SE, Palumbo MA, Bohlman HH. Increased rate of arthrodesis with strut grafting after multilevel anterior cervical decompression. Spine (Phila Pa 1976). 2002;27(2):146-51. doi: 10.1097/00007632-200201150-00005.

23. Naderi S, Alberstone CD, Rupp FW, Benzel EC, Baldwin NG. Cervical spondylotic myelopathy treated with corpectomy: technique and results in 44 patients. Neurosurg Focus. 1996;1 (6):e5; discussion 1 p following e5. doi: 10.3171/foc.1996.1.6.6.

24. Swank ML, Lowery GL, Bhat AL, McDonough RF. Anterior cervical allograft arthrodesis and instrumentation: multilevel interbody grafting or strut graft reconstruction. Eur Spine J. 1997:6(2):138-43. doi: 10.1007/BF01358747.

25. Vaccaro AR, Falatyn SP, Scuderi GJ, Eismont FJ, McGuire RA, Singh K, et al. Early failure of long segment anterior cervical plate fixation. J Spinal Disord. 1998:11(5):410-5.

26. Law MD, Bernhardt M, White AA. Evaluation and management of cervical spondylotic myelopathy. Instr Course Lect. 1995;44:99-110. 